\title{
Konsep Tanggung Jawab Sosial Perusahaan Melalui Pendekatan Filsafat Hukum Islam
}

\author{
Satria Sukananda \\ Magister Ilmu Hukum Fakultas Hukum Universitas Islam Indonesia \\ Jl. Cik Di Tiro No. 1 Yogyakarta \\ artisukananda@gmail.com
}

\begin{abstract}
Abstrak
Almost all theories, concepts, and practices of CSR are based on cultural values, ethics and beliefs of the western societies, especially Europe and America. Although the concept of CSR is not necessarily fully practiced by companies in all countries, especially for those that have different ethics, cultures and beliefs, such as Islamic companies. The problem that becomes the focus of the study in this research is the concept of CSR which is examined through the philosophical approach of Islamic law. This study applies a normative legal research method with both legislative and conceptual approach. The results show that CSR, when examined through the approach of Islamic legal philosophy with the methods of ta'ili and the Qiyas ijtihad, is indicated that the concept of social responsibility had long existed in Islam even though the Western concept of CSR had only emerged in the fourth wave of business principles in the 1930s. Therefore, the principle of social responsibility that has been outlined in the Al-Qur'an and Sunnah must be used as a guidance for the lives of Muslims in various activities including in Islamic business.
\end{abstract}

Keywords: Al-Qur'an and sunnah; corporate social responsibility; Islamic legal philosophy; ta'lili method

\begin{abstract}
Abstrak
Hampir semua teori, konsep, dan praktik CSR yang ada mendasarkan pada nilai-nilai budaya, etika dan keyakinan masyarakat barat, khususnya Eropa dan Amerika. Padahal konsep CSR tersebut belum tentu sepenuhnya dapat dipraktikkan oleh perusahaan di semua negara, terutama bagi perusahaan yang memiliki etika, budaya dan keyakinan yang berbeda, seperti perusahaan Islam. Permasalahan yang menjadi fokus kajian dalam penelitian ini adalah konsep CSR yang dikaji melalui pendekatan filsafat hukum Islam. Penelitian ini menggunakan metode penelitian hukum normatif dengan pendekatan perundang-undangan dan pendekatan konsep. Hasil penelitian menyimpulkan bahwa, CSR bila dikaji melalui pendekatan filsafat hukum Islam dengan metode ta'lili dan metode ijtihad Qiyas, maka menunjukkan bahwa konsep tanggung jawab sosial telah lama ada dalam Islam walaupun konsep CSR barat baru muncul pada prinsip bisnis gelombang ke empat (fourth wave) pada tahun 1930-an. Karena itu, prinsip tanggung jawab sosial yang telah digariskan dalam Al-Quran dan Sunnah harus dijadikan pedoman bagi kehidupan kaum muslimin dalam berbagai kegiatan termasuk dalam bisnis Islam.
\end{abstract}

Kata-kata Kunci: Al-Qur'an dan sunnah; filsafat hukum Islam; metode ta'lili; tanggungjawab sosial perusahaan 


\section{Pendahuluan}

David C. Korten dalam bukunya When Corporation Rule The World (1995) menyebut, bahwa dalam paruh akhir abad keduapuluh terjadi perubahan yang luar biasa dari sejarah manusia. ${ }^{1}$ Temuan yang dicapai oleh ilmu pengetahuan telah menghantarkan peradaban menjadi sangat maju, seperti terwujudnya perjalanan luar angkasa, komputer, kecanggihan pengobatan hingga perlengkapan hidup sehari-hari. Ini semua dapat dinikmati oleh masyarakat karena industrialiasasi yang dilakukan oleh korporasi. Korporasi telah menjelma menjadi institusi yang sangat dominan memengaruhi setiap kehidupan bangsa, bahkan melebihi kekuasaan negara. Perihal inilah yang melahirkan wacana Tanggung Jawab Sosial Perusahaan (Corporate Social Responsibility) yang selanjutnya disebut CSR. ${ }^{2}$

Bryant Jr dan Susan E Mehrtens, menawarkan paradigma baru mengenai tujuan perusahaan pada gelombang keempat (fourth wave), yakni untuk melayani masyarakat (serve as global steward). ${ }^{3}$ Hingga munculnya konsep triple bottom lines, bahwa korporasi bertujuan untuk mencari keuntungan (profit), menciptakan kesejahteraan sosial (people) dan melestarikan lingkungan hidup (planet) ${ }^{4}$

Interfaith Center on Corporate Responsibility (ICCR) juga telah mengeluarkan "Principles for Global Corporate Responsibility". ${ }^{5}$ Walaupun ini bukan standar CSR, akan tetapi mengandung prinsip-prinsip yang disepakati bersama oleh setiap anggota ICCR terhadap tanggung jawab sosial. Prinsip-prinsip yang dipakai tersebut didasarkan pada isu-isu yang menjadi perhatian pelaksanaan di institusi yang dibangun atas dasar nilai-nilai agama Yahudi dan Kristen. ICCR sendiri beranggotakan lebih dari 275 institusi yang tersebar di kawasan Amerika,

1 David C Korten, When Corporation Rule The World, Terjemahan oleh Agus Maulana, Rajawali Pers, Jakarta, 1995, hlm. 204 di kutip dari Mukti Fajar ND, Tanggung Jawab Sosial Perusabaan di Indonesia Mandatory vs Voluntary Studi Tentang Penerapan Ketentuan Corporate Social Responsibility Pada Perusahaan Multi Nasional, Swasta Nasional dan Badan Usaha Milik. Negara, Pustaka Pelajar,Yogyakarta, 2009, hlm. Pengantar

2 Bowen (1953) mendefenisikan CSR adalah keputusan perusahaan unt uk memberikan nilai-nilai positif bagi masyarakat. Davis (1973) mendefinisikan CSR sebagai usaha ikhlas dari perusahaan untuk menciptakan keseimbangan ekonomi dan keadaan sosial masyarakat yang baik. Muhammad Yasir Yusuf, Islamic Corporate Social Responsibility (I-CSR) Pada Lembaga Kenangan Syariah (LKS) Teori dan Praktik. Kencana Prenada Media Group, Jakarta, 2017, hlm. 1

${ }^{3}$ Mukti Fajar ND., Tanggung Jawab Sosial Perusabaan di Indonesia..., Op. Cit., hlm. 1

${ }^{4}$ Ibid.

5Ibid., hlm. 13 
Kanada, dan Inggris. Prinsip-prinsip CSR tersebut disusun mengikuti cara pandang masyarakat barat terhadap perusahaan. Cara pandang masyarakat barat tersebut kemungkinan besar memengaruhi secara luas dalam proses pembentukan prinsip-prinsip CSR yang dipakai oleh perusahaan-perusahaan di Barat. Hal ini dikemudian memberi dampak terhadap perusahaan yang berkembang dan tumbuh di luar benua Eropa dan Amerika seperti Asia dan Afrika. Perusahaan-perusahaan di Asia dan Afrika menjadikan CSR Barat sebagai contoh pelaksanaan CSR di Asia dan Afrika. ${ }^{6}$

Konsep CSR yang dipraktikkan di Barat bukanlah satu-satunya konsep CSR yang seratus persen dapat dipraktikkan oleh perusahaan di semua negara. Setiap perusahaan dapat melaksanakan CSR berdasarkan etika, budaya dan keyakinan yang belaku dalam masyarakat di suatu negara. Banyak faktor yang boleh memengaruhi bentuk praktik CSR pada suatu kawasan, seperti faktor yang timbul dari isu-isu keagamaan, lingkungan, budaya dan keadaan sosial masyarakat di suatu tempat.

Apabila melihat faktor-faktor kemunculan CSR di barat, pada dasarnya dapat diketahui bahwa: pertama, CSR di barat lahir karena adanya jurang antara pemilik perusahaan dan masyarakat dari aspek materi. Masyarakat barat memandang perusahaan hanya berusaha untuk mengumpulkan keuntungan saja, bersifat sekuler (terpisah dengan agama), mementingkan kepentingan diri sendiri dengan mengesampingkan hak orang lain. Pandangan masyarakat barat inilah yang menimbulkan banyak permasalahan sosial seperti jurang ekonomi, banyaknya masyarakat miskin, persoalan lingkungan sosial, diskriminasi agama, sehingga memberikan kontribusi sampai pada aspek penurunan pertumbuhan ekonmi dalam suatu negara. Oleh karena itu, kelahiran konsep CSR dalam pandangan barat lebih bertumpu pada pemenuhan unsur-unsur keadilan dalam persoalan materi masyarakat sekitar dan mengesampingkan kedudukan nilainilai rohani dalam sisi praktiknya. Ketika pemenuhan unsur materi tidak seimbang dengan pemenuhan unsur spiritual, akibatnya akan muncul masalah sosial yang baru dalam praktik CSR. 
Kedua, teori-teori CSR yang telah berkembang di barat juga didasarkan pada pendekatan rasional semata. Akibatnya, pandangan dunia barat relatif dan selalu berubah dipengaruhi hasil pengamatan empirik terhadap latar belakang masyarakat, budaya dan isu yang menyebabkan ketidakadilan. Implementasi konsep CSR bagi perusahaan-perusahaan di negara barat yang memiliki norma, etika, budaya dan keyakinan yang relatif berbeda dengan konsep perusahaan Islam, akan menimbulkan pertentangan antara pertimbangan budaya dan keyakinan disatu sisi. ${ }^{7}$ Pada sisi yang lain bahwa manfaat yang diharapkan dari program CSR tidak akan tercapai secara maksimal. Hal ini tentunya dapat menimbulkan kesan buruk bagi pelaksanaan CSR. Kesan buruk dimaksud misalnya, perusahaan Islam akan disamakan dengan perusahaan-perusahaan yang lain padahal dasar kedua perusahaan ini sangat jauh berbeda, baik dari sisi operasional CSR maupun aspek filosofinya. ${ }^{8}$

Penting halnya untuk mengkaji konsep dan prinsip tanggung jawab sosial perusahaan yang awalnya berpandangan dan berdasar pada prinsip-prinsip barat untuk kemudian dikaji melalui pendekatan filsafat hukum Islam dengan menggunakan konsep, metode dan prinsip-prinsip hukum Islam. Kajian ini penting untuk menciptakan paradigma atau pandangan baru mengenai konsep CSR yang berdasar pada prinsip hukum Islam yaitu Islamic Corporate Social Responsibility, sehingga perusahaan-perusahaan Islam menemukan aktivitas bisnis yang ideal dengan menerapkan Islamic Corporate Social Responsibility.

\section{Rumusan Masalah}

Permasalahan yang menjadi fokus kajian dalam penelitian ini adalah bagaimana konsep tanggung jawab sosial perusahaan (Corporate Social Responsibility) jika dikaji melalui pendekatan filsafat hukum Islam?

7 Perusahaan yang dikendalikan oleh nilai-nilai dasar Islam, dalam aktivitas ekonomi, individu harus memperhintungan etika dan prinsip yang bersumber dari Quran dan Sunnnah. Di dalam buku Abd. Shomad, Hukum Islam Penormaan Prinsip Syariah Dalam Hukum Indonesia, Kencana Prenada Media Group, Jakarta, 2012, hlm. 76

${ }^{8}$ Muhammad Yasir Yusuf, Islamic Corporate Social Responsibility..., Op. Cit., hlm. 9 


\section{Tujuan Penelitian}

Mengetahui dan menganalisis konsep tanggung jawab sosial perusahaan (Corporate Social Responsibility) jika dikaji melalui pendekatan filsafat hukum Islam.

\section{Metode Penelitian}

Penelitian ini merupakan penelitian hukum normatif dengan menggunakan studi kepustakaan yaitu penelitian hukum yang meletakkan hukum sebagai sebuah bangunan sistem norma. ${ }^{9}$ Penelitian ini menggunakan bahan hukum primer, sekunder, dan tersier. ${ }^{10}$ Bahan hukum primer dalam penelitian ini, antara lain Undang-Undang Dasar Negara Republik Indonesia Tahun 1945; UndangUndang Nomor 25 Tahun 2007 tentang Penanaman Modal; Undang-Undang Nomor 40 Tahun 2007 tentang Perseroan Terbatas; Peraturan Pemerintah Nomor 47 Tahun 2012 tentang Tanggung Jawab Sosial dan Lingkungan. Bahan hukum sekunder, terdiri atas buku-buku ilmiah terkait; hasil penelitian terkait; jurnaljurnal terkait baik nasional atau internasional; doktrin, pendapat, dan kesaksian ahli hukum perusahaan terkait dengan tanggung jawab sosial perusahaan baik tertulis maupun yang tidak tertulis. Bahan hukum tersier, berupa kamus hukum dan ensiklopedi. Penelitian ini menggunakan pendekatan perundang-undangan dan konseptual. Analisis bahan hukum menggunakan metode deduktif, yang berpangkal dari prinsip-prinsip dasar kemudian menghadirkan objek yang hendak diteliti, atau dari prinsip-prinsip umum menuju prinsip-prinsip khusus. ${ }^{11}$

${ }_{9}^{9}$ Mukti Fajar N.D dan Yulianto Achmad, Dualisme Penelitian Hukum Normatif \& Empiris, Penerbit Pustaka Pelajar, Yogyakarta, hlm. 34

${ }^{10}$ Amiruddin, dan H. Zainal Asikin, Pengantar Metode Penelitian Hukum, PT Raja Grafindo Persada, Jakarta, 2003, hlm.118.

${ }^{11}$ Mukti Fajar N.D dan Yulianto Achmad, Dualisme Penelitian Hukum Normatif.., Op.Cit., hlm. 42. 


\section{Hasil Penelitian dan Pembahasan}

\section{Tanggung Jawab Sosial Perusahaan (Corporate Social Responsibility) Melalui Pendekatan Filsafat Hukum Islam}

\section{Tinjauan Umum Tanggung Jawab Sosial Perusahaan (Corporate Social Responsibility)}

CSR merupakan konsep yang terus berkembang. CSR belum memiliki sebuah definisi standar maupun seperangkat kriteria spesifik yang diakui secara penuh oleh pihak-pihak yang terlibat di dalamnya. Secara konseptual, CSR juga bersinggungan dan bahkan sering dipertukarkan dengan frasa lain, seperti Corporate Responsibility, Corporate Sustainability, Corporate Accountability, Corporate Citizenship, dan Corporate Stewarship.

Perilaku atau cara perusahaan dalam memerhatikan dan melibatkan Share Holder, pekerja, pelanggan, pemasok, pemerintah, LSM, lembaga internasional dan Stake Holder lainnya merupakan konsep utama CSR. Kepatuhan perusahaan terhadap hukum dan peraturan-peraturan yang menyangkut aspek ekonomi, lingkungan dan sosial bisa dijadikan indikator atau perangkat formal dalam mengukur kinerja CSR suatu perusahaan, namun, CSR sering kali dimaknai sebagai komitmen dan kegiatan-kegiatan sektor swasta yang lebih dari sekedar kepatuhan terhadap hukum.

Perusahaan tidak lagi dihadapkan pada tanggung jawab yang berpijak pada single bottom line, yaitu nilai perusahaan (corporate value) yang direfleksikan dalam kondisi keuangannya (finansial) saja, tetapi tanggung jawab perusahaan harus berpijak pada sosial dan lingkungan. ${ }^{12}$ Pengertian CSR yang relatif lebih muda dipahami dan dioperasionalkan adalah sebagaimana konsep Tripple Bottom Line (Profit, Planet dan People) yang digagas oleh Elkington. Elkinston menegaskan bahwa perusahaan yang baik tidak hanya memburu keuntungan ekonomi belaka (profit), melainkan jugaharus memiliki kepedulian terhadap kelestarian lingkungan (planet) dan kesejahteraan masyarakat (people). ${ }^{13}$

12 Badan Pembinaan Hukum Nasional Departemen Hukum dan HAM Republik Indonesia, Tanggung Jawab Sosial Perusahan, Kementerian Hukum dan HAM, Jakarta, 2009, hlm. 4

${ }^{13}$ Ibid. 


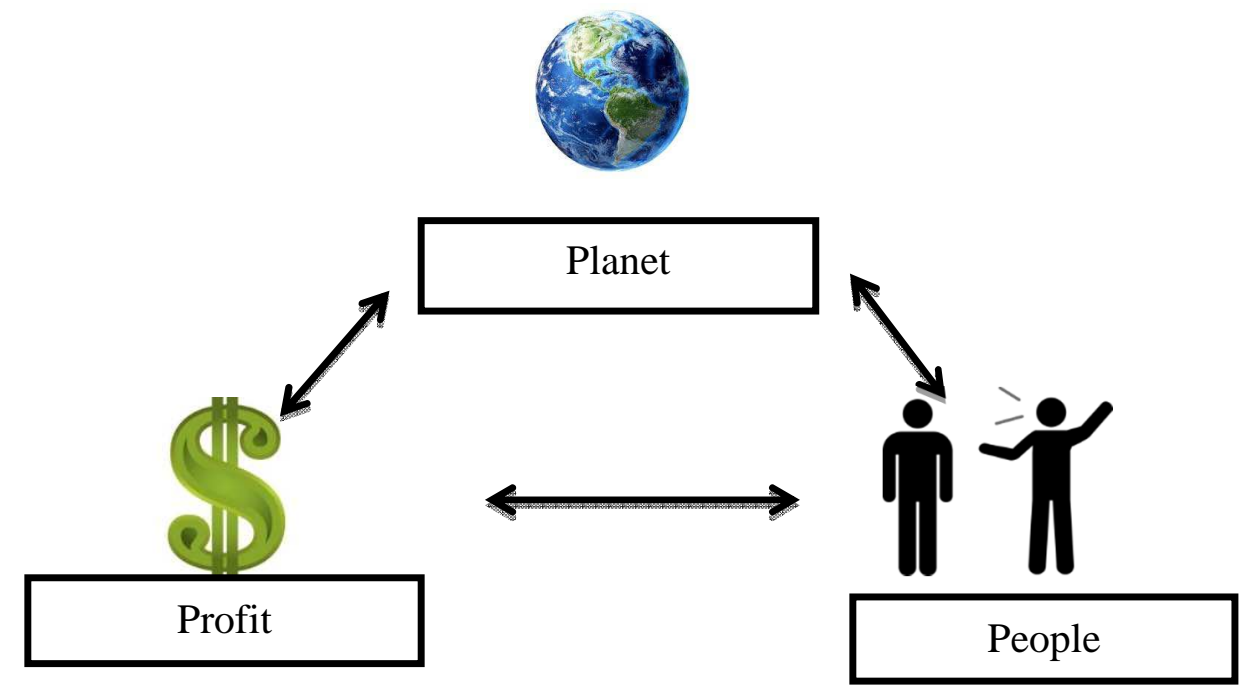

Gambar 1.1 Konsep 3P 14

Berkaitan dengan konsep tersebut, Edi Suharto menambahkan dengan satu line tambahan, yaitu procedure.CSR kemudian dipahami sebagai sebuah kepedulian perusahaan yang menyisihkan sebagian keuntungannya (profit) bagi kepentingan pembangunan manusia (people) dan lingkungan (planet) secara berkelanjutan berdasarkan prosedur (procedure) yang tepat dan professional". ${ }^{15} \mathrm{Di}$ Indonesia, CSR juga diatur secara imperatif dalam Pasal 1 Undang-Undang Nomor 40 Tahun 2007 tentang Perseroan Terbatas yang mendefinisikan bahwa:

“Tanggung Jawab Sosial Perusahaan dan Lingkungan adalah Komitmen Perseroan untuk berperan serta dalam pembangunan ekonomi berkelanjutan guna meningkatkan kualitas kehidupan dan lingkungan yang bermanfaat, baik bagi perseroan sendiri, komunitas setempat maupun masyarakat pada umumnya."

Selanjutnya CSR diatur dalam Pasal 74 Undang-Undang Nomor 40 Tahun 2007 tentang Perseroan Terbatas,yang mengatur antara lain:

1) Perseroan yang menjalankan kegiatan usahanya di bidang dan/atau berkaitan dengan sumber daya alam wajib melaksanakan Tanggung Jawab Sosial dan Lingkungan.

2) Tanggung Jawab Sosial dan Lingkungan sebagaimana dimaksud pada ayat (1) merupakan kewajiban Perseroan yang dianggarkan dan diperhitungkan sebagai biaya Perseroan yang pelaksanaannya dilakukan dengan memerhatikan kepatutan dan kewajaran.

\footnotetext{
14 www.ekatjicptafoundation.org di dalam buku Edi Suharto, CSR \& Comdev investasi Kreatif Perusahaan di Era Globalisasi, Alfabeta, Bandung, 2010, hlm. 5

${ }^{15}$ Ibid.
} 
3) Perseroan yang tidak melaksanakan kewajiban sebagaimana dimaksud pada ayat (1) dikenai sanksi sesuai dengan ketentuan peraturan perundang-undangan.

4) Ketentuan lebih lanjut mengenai Tanggung Jawab Sosial dan Lingkungan diatur dengan Peraturan Pemerintah.

Ketantuan di atas dilatarbelakangi oleh amanat Undang-Undang Dasar Negara Republik Indonesia Tahun 1945 mengenai perekonomian nasional dan kesejahteraan sosial. ${ }^{16}$ Selain itu berdasarkan prinsip pembangunan berkelanjutan, dalam hal ini lembaga legislatif, berkeinginan untuk mencegah dan mengurangi rusaknya lingkungan yang diakibatkan oleh operasional korporasi yang tidak memerhatikan lingkungan hidup masyarakat disekitarnya. ${ }^{17}$

CSR juga di atur dalam Pasal 15 huruf b Undang-Undang Nomor 25 Tahun 2007 tentang Penanaman Modal, yang dalam penjelasannya menyebutkan bahwa:

"yang dimaksud dengan Tanggung Jawab Sosial Perusahaan adalah Tanggung Jawab yang melekat pada setiap perusahaan penanaman modal untuk menciptakan hubungan yang serasi, seimbang dan sesuai dengan lingkungan, nilai, moral, norma dan budaya masyarakat setempat."18

Tanggung jawab hukum CSR juga diatur di dalam Pasal 7 Peraturan Pemerintah Nomor 42 Tahun 2012 tentang Tanggung Jawab Sosial dan Lingkungan, bahwa perseroan yang tidak melaksanakan tanggung jawab sosial dan lingkungan di kenai sanksi sesuai dengan ketentuan peraturan perundangundangan. Sanksi ini dimaksud sebagai kosekuensi atas pengaturan tersebut, agar memiliki daya atur, daya ikat, dan daya paksa. Tanggung jawab perusahaan yang semula adalah responsibility (tanggung jawab non hukum) akan berubah menjadi liability (tanggung jawab hukum), dalam arti bahwa CSR menjadi objek

${ }^{16}$ Risalah Rapat Panitia Khusus, Rancangan Undang-Undang Tentang Perseroan Terbatas, Masa Sidang I, Jumat, 1 Desember 2006 di dalam buku Mukti Fajar ND., Tanggung Jawab Sosial Perusabaandi Indonesia..., Op. Cit., hlm. 1

${ }^{17}$ Risalah Rapat Panitia Khusus, Rancangan Undang-Undang Tentang Perseroan Terbatas, Masa Sidang III, Kamis Februari 2007 di dalamm buku Mukti Fajar ND., Tanggung Jawab Sosial Perusahaandi Indonesia..., Ibid,. hlm. 1

18 Penjelasan Pasal 15 Huruf b Undang-Undang Nomor 25 Tahun 2007 tentang Penanaman Modal 
hukum yang dapat diikat dan dipaksakan, dan apabila tidak dilaksanakan akan dikenakan sanksi. ${ }^{19}$

Menurut konsep CSR dan ketentuan normatif peraturan perundangundangan yang telah dijelaskan diatas, bahwa CSR merupakan suatu tanggung jawab yang melekat oleh sebuah perusahaan terhadap masyarakat sekitar. Tanggung jawab yang melekat tersebut diwujudkan dalam bentuk peran serta sebuah perusahan sebagai bentuk dari perekonomian nasional yang diselenggarakan atas demokrasi ekonomi dengan prinsip kebersamaan, efisensi berkeadilan, berkelanjutan, berwawasan lingkungan, kemandirian, serta menjaga keseimbangan kemajuan dan kesatuan ekonomi nasional. Upaya tersebut tentunya perlu didukung dengan kelembagaan perekonomian yang kokoh dalam rangka mewujudkan kesejahteraan masyarakat. ${ }^{20}$

\section{Tanggung Jawab Sosial Perusahaan (Corporate Social Responsibility) dalam Pandangan Islam}

Secara filosofis tanggung Jawab sosial dalam Islam bukanlah merupakan perkara asing. Tanggung Jawab sosial sudah mulai ada dan dipraktikkan sejak 14 abad lalu. Pembahasan mengenai tanggung jawab sosial sangat sering disebutkan dalam Al-Quran. Al Quran selalu menghubungkan antara kesuksesan berbisnis dan pertumbuhan ekonomi yang dipengaruhi oleh moral para pengusaha dalam menjalankan bisnis. ${ }^{21}$ Sesuai dengan firman Allah SWT yang artinya: "Dan sempurnakanlah timbangan apabila kamu menakar dan timbanglah dengan neraca yang benar. Itulah yang lebih utama (bagimu) dan lebih baik akibatnya." (QS. Al-isra: 35)

Perhatian Islam terhadap keuntungan bisnis tidak mengabaikan aspekaspek moral dalam mencapai keuntungan tersebut. Hal ini menunjukkan bahwa

\footnotetext{
${ }^{19}$ Badan Pembinaan Hukum Nasional Departemen Hukum dan Ham Republik Indonesia, Tanggung Jawab Sosial Perusahan..., Op. Cit., hlm. 4

20 Jejen Hendar, Corporate Social Responsibility (CSR) Dalam Perspektif Hukum Islam, https://media.neliti.com/media/publications/164479-ID-none.pdf , hlm. 40, diakses pada tanggal 26 Maret 2019

21 Al-Quranlah yang menjadi mata air yang berpokok kepadanya segala mata air yang diminum untuk menetapkan hukum, dan tempat pengambilan yang menjadi sandaran segala dasar dan cabang. Dari Al-Quranlah segala dalil memperoleh atau mengambil kekuatannya. Oleh karena al-Quran disebut sebagai dasar Syariah atau Mashdarul Mashaadir. Dalam al-Quran ini telah diterangkan segala keperluan manusia. Tidak ada suatu aturan yang dikehendaki atau dibutuhi umat, yang tidak terdapat pokoknya di dalam Al-Quran, "tiadalah kami alpakan sesuatupun dalam Al-Kitab (Quran)" (QS. Al-An'am: 38) di dalam buku Abddul Ghofur Anshori \& Yulkarnain Harahab, Hukum Islam Dinamika dan Perkembanganya di Indonesia, Thafa Media, Yogyakarta, 2008, hlm. 38.
} 
dalam Islam terdapat hubungan yang sangat erat antara ekonomi dan moral, keduanya merupakan sesuatu yang tidak boleh dipisahkan.

Filsafat hukum Islam telah memberikan prinsip komitmen perusahaan kepada masyarakat yang sering dikenal dengan zakat. Zakat ini merupakan salah satu ciri dari agama Islam yang memiliki sifat kemanusiaan, sehingga zakat diwajibkan kepada orang kaya yang hartanya telah mencapai nisab. Selain itu, zakat juga diperuntukkan kepada orang-orang yang membutuhkan.22 Di samping itu, dalam Al-Qur'an telah dijelaskan pula mengenai kewajiban untuk saling tolong menolong, yakni dalam surat Al-Maidah: 2, "dan tolong-menolonglah kamu dalam (mengerjakan) kebajikan dan takwa, dan jangan tolong-menolong dalam berbuat dosa dan pelanggaran...".

Al-Qur'an dengan jelas menentukan bahwa tolong menolong bagi umat Islam merupakan suatu kewajiban dan keharusan. Di samping itu, Islam juga mewajibkan membayar zakat. Perintah melaksanakan zakat tersebut sangat banyak dikarenakan pentingnya fungsi zakat, antara lain dalam surat At-Taubah: 103, bahwa"Ambilah zakat dari sebagian harta mereka, dengan zakat itu kamu membersihkan dan mensucikan...".

Perintah mengenai zakat ini masih banyak lagi, karena zakat mengandung hikmah yang begitu besar serta bersifat rohaniah dan filosofis. Hikmah tersebut digambarkan dalam berbagai ayat dalam Al-Qur'an dan Hadits, diantaranya ialah:23

a. Mensyukuri karunia ilahi, menumbuh suburkan harta dan pahala serta membersihkan diri dari sifat-sifat kikir, dengki, iri serta dosa;

b. Melindungi masyarakat dari bahaya kemiskinan dan akibat kemelaratan;

c. Mewujudkan rasa soidaritas dan kasih sayang antar sesama manusia;

d. Manifestasi kegotongroyongan dan tolong-menolong dalam kebaikan dan taqwa;

e. Mengurangi kefakir-miskinan yang merupakan masalah sosial;

f. Membina dan mengembangkan stabilitas sosial;

g. Salah satu jalan mewujudkan keadilan.

22 Ismail Muhammad Syah, dkk, Filsafat Hukum Islam, Bumi Aksara, Jakarta, 1999, hlm. 118.

${ }^{23}$ Mohammad Daud Ali, Sistem Ekonomi Islam Zakat dan Wakaf, UI Press, Jakarta, 1988, hlm. 118. 
Melihat hikmah yang ditimbulkan akibat pelaksanaan zakat ini, penulis mencoba menarik suatu garis keterkaitan antara tanggung jawab sosial perusahaan dengan zakat. Zakat disini yang diatur oleh Islam ialah zakat perusahaan/zakat pendapatan/zakat perdagangan, seperti yang dituliskan oleh Mohammad Daud Ali. ${ }^{24}$ Dengan nisab harta tersebut sejumlah ataupun senilai dengan 96 gram emas murni, dengan hawl selama 1 tahun, maka kadar zakat yang dikeluarkan adalah 2,5\%. Ibnu al Mundzir mengatakan para ahli ilmu sepakat bahwa dalam barang-barang yang dimaksudkan sebagai barang-barang dagangan, zakatnya dikeluarkan ketika telah mencapai hawl. ${ }^{25}$ Adapun dalil tentang zakat perdagangan ialah, "Hai orang-orang yang beriman, nafkahkanlah (di jalan Allah) sebagian dari hasil usahamu yang baik-baik...". ${ }^{26}$

Selain itu mengenai zakat sebuah perusahaan dibagi menjadi dua kategori yakni: (1) perusahaan yang hanya menggunakan alat-alat sederhana dan yang modal utamanya untuk membeli bahan-bahan pokok, membayar upah karyawan dan ongkos-ongkos; dan (2) perusahaan yang modal utamanya untuk alat-alat canggih yang amat mahal harganya. ${ }^{27}$

Jenis perusahaan pertama, perhitungan zakatnya yakni menghitung saldo uang di kas dan simpanan di bank pada akhir tahun, ditambah persediaan bahanbahan dan barang jadi serta piutang yang lancar. Kemudian jumlah itu dikurangi beban hutang yang harus dibayar lalu dikeluarkan zakatnya sebanyak 2,5\% dari jumlah aset yang tersisa. Untuk jenis perusahaan yang kedua, zakat yang dikeluarkan dilakukan dengan cara tidak dihitung dari harga mesin-mesin tersebut, tetapi dari hasil produksinya dan mengeluarkan zakatnya sebesar $10 \%$. Perbedaan tersebut dikarenakan jika yang pertama menggunakan seluruh modalnya untuk diputarkan sehingga dianggap sebagai harta yang tumbuh dan berkembang, jika yang kedua sebagian besar dari modalnya digunakan untuk membeli alat-alat mahal sehingga tidak dianggap sebagai harta yang tumbuh dan

\footnotetext{
${ }^{24}$ Ibid., hlm. 58.

${ }^{25}$ Wahbah Al-Zuhayly, Zakat Kajian Berbagai Mą̧ab, Remaja Rosdakarya, Bandung, 2008, hlm. 169 -170 ${ }^{26}$ Q.S. Al-Baqarab: 167

${ }^{27}$ Muhammad Bagir Al- Habsyi, Fiqih Praktis Menurut Al-Qur'an, Assunab, Pendapat Para Ulama, Mirzan, Bandung, 1999, hlm. 298.
} 
berkembang melainkan dihitung dan dikeluarkan hanya dari hasil laba yang diperoleh saja. ${ }^{28}$

Uraian di atas menunjukkan bahwa hukum Islam telah lama mengatur mengenai tanggung jawab sosial sebuah perusahaan, namun dalam hal ini digambarkan atau diformulasikan dalam bentuk zakat. Apabila ditelaah lebih mendalam, hubungan antara zakat dengan kepedulian atau tanggung jawab sosial perusahaan ternyata saling memiliki keterkaitan, dan dapat dikatakan memiliki makna yang sama. Ketika berbicara tentang perindustrian, Islampun memiliki konsep dasar ekonomi Islam, dengan mendasarkan pada 3 pilar pokok yakni: ${ }^{29}$

a. Aqidah, komponen ajaran Islam yang mengatur keyakinan atas keberadaan dan kekuasaan Allah, sehingga harus menjadi keimanan seorang muslim manakala melakukan berbagai aktivias di muka bumi semata-mata untuk mendapat ridha Allah.

b. Syari'ah komponen ajaran Islam yang mengatur tentang kehidupan seorang muslim baik dalam bidang ibadah maupun dalam bidang muamalah yang merupakan aktualisasi aqidah yang menjadi keyakinan.

c. Akhlaq, landas perilaku dan kepribadian yang akan mencirikan dirinya sebagai seorang muslim yang taat berdasarkan syari'at dan aqidah yang menjadi pedoman hidupnya sehingga disebut memiliki akhlaqul karimah.

Kegiatan CSR dari sudut etika bisnis dapat merujuk pendapat Syed Nawab Heidar Naqwi, yang menguraikan prinsip-prinsip ekonomi Islam, meliputi:30

a. Tauhid, dalam hal ini tauhid merupakan filsafat ekonomi Islam yang menjadi orientasi dasar dari ilmu ekonomi, yang paradigmanya relevan dengan nilai logik, etik dan estetik yang dapat difungsionalisasikan ke tingkah laku ekonomi manusia. Selain itu tauhid juga dalam ekonomi mengantarkan para pelaku ekonomi untuk berkeyakinan bahwa harta benda adalah milik Allah semata.

b. Keseimbangan, bahwa ekonomi memiliki kekuatan untuk membentuk mozaik pemikiran seseorang bahwa sikap keseimbangan dapat mengantarkan manusia kepada keadaan keharusan adanya fungsi sosial bagi harta benda, artinya praktik monopoli pemusatan kekuatan ekonomi, penguasaan pangsa pasar dan sebagainya harus dihindari.

${ }^{28}$ Ibid., hlm. 299. 24.

${ }^{29}$ Amir Mahmud, Bank Syariah Teori, Kebijakan dan Studi Empiris di Indonesia, Erlangga, Jakarta, 2010, hlm.

${ }^{30}$ Muhammad, Aspek Hukum dalam Mu'amalat, Graha Ilmu, Yogyakarta, 2007, hlm. 82-83. 
c. Kehendak bebas, hal ini merupakan prinsip yang mengantarkan manusia meyakini bahwa Allah tidak hanya memiliki kebebasan mutlak, tetapi dia juga dengan sifat Rahman dan Rahimnya menganugerahkan kepada manusia kebebasan untuk memilih.

Merujuk tiga prinsip yang dikemukan oleh Syed Nawab di atas, penulis melihat bahwa ketiga hal tersebut merupakan suatu landasan dalam melakukan perekonomian yang memiliki pondasi terhadap kepedulian sesama, yakni kepedulian terhadap lingkungan dan sosial. CSR yang tidak terlepas dari prinsip sosial dan lingkungan ini, dapat dikategorikan mempunyai etika bisnis yang arif, sedang kanetika bisnis tidak terlepas dari suatu nilai keadilan, diantaranya adalah keadilan distributif Islam. Menurut Munawar Iqbal, distributive justice dalam Islam tercermin dalam 3 hal berikut: ${ }^{31}$

a. Jaminan terpenuhinya kebutuhan dasar bagi semua.

b. Objektivitas atau keadilan tetapi bukan persamaan dalam pendapat individu.

c. Pembatasan ketidakmerataan ekstream dalam pendapat kekayaan individu.

Basis pelaksanaan CSR jika merujuk ajaran Islam pada intinya ialah kekayaan tersebut tidak boleh menumpuk pada satu kelompok orang tertentu saja. ${ }^{32}$ Islam sangat mengutuk perilaku mengumpulkan harta benda tanpa memedulikan orang lain. Allah SWT memeringatkan dalam Al-Qur'an Surat AlHumazah: 1-4 berikut:

“Celakalah bagi setiap pengumpat lagi pencela (1), yang mengumpulkan harta dan menghitung-hitung (2), dia (manusia) mengira bahwa hartanya itu dapat mengekalkannya (3), sekali-kali tidak! Sesungguhnya dia benar-benar akan dilemparkan ke dalam (neraka) Huthamah (4).

Perusahaan tidak diperkenankan hanya menggunakan keuntungannya tanpa beramal. CSR sejatinya merupakan mekanisme sosial untuk mendistribusikan harta yang dititipkan oleh Allah SWT kepada yang lebih berhak menerimanya. Perhatian aspek moral dalam bisnis juga ditegaskan Rasulullah dalam Hadist yang diriwayatkan oleh Malik ibn Annas, yaitu:

${ }^{31}$ Faisal Badroen, dkk, Etika bisnis dalam Islam, Kencana Prenada Media Group, Jakarta, 2006, hlm. 49.

32 Joko Prastowo dan Miftahul Huda, Corporate Social Responsibility Kunci Meraib Kemuliaan Bisnis, Samudra Biru, Yogyakarta, 2011, hlm. 74. 
"seorang buruh/pekerja (lelaki atau perempuan) berhak paling sedikit memeroleh makanan dan pakaian yang baik dengan ukuran yang layak dan tidak dibebani dengan pekerjaan yang diluar batas kemampuannya." (HR. Malik, 795:980)33

Hadis di atas menuntun pada pemahaman bahwa upah minimum mestilah upah yang memungkinkan buruh atau pekerja untuk memeroleh makanan dan pakaian yang layak dan cukup untuk dirinya dan keluarganya. Ukuran ini dipandang oleh sahabat-sahabat nabi sebagai batas minimum untuk mempertahankan ukuran spiritual masyarakat Islam. ${ }^{34}$ Sementara itu, Ustman ibn Affan telah menyatakan:

“Janganlah kamu bebani buruh perempuan di luar kemampuan dalam usahanya mencari penghidupan, karena bila kamu melakukan hal itu kepadanya, ia mungkin akan melakukan perbuatan-perbuatan yang bertentangan dengan moral, dan jangan kamu bebani bawahanmu yang lelaki dengan tugas yang di luar batas kemampuannya, karena bila kamu melakukan itu terhadapnya, mungkin ia akan melakukan pencurian." (Malik, $795: 981)^{35}$

Hal ini sejalan dengan prinsip-prinsip hukum Islam menurut Muhammad Syukri Albani Nasution,yaitu meniadakan kesempitan dan kesukaran; sedikit pembebanan; memerhatikan kemaslahatan manusia; mewujudkan keadilan. ${ }^{36}$ Pandangan ini seirama dengan pendapat Juhaya S. Praja, mengenai prinsipprinsip hukum Islam, yaituprinsip keadilan ( $\left.a l^{\prime} a d l\right) ;$ kemerdekaan atau kebabasan (al-hurriyyah); persamaan atau egalite (al-musa'wah); tolong-menolong (alta'awun); toleransi (tasa'muh). ${ }^{37}$ Sjaichul Hadi Permono, juga mengidentifikasi beberapa prinsip ekonomi Islam yang berkaitan dengan penjelasan di atas, yakni: prinsip keadilan; prinsip al ihsan (berbuat kebaikan); prinsip al mas'uliyah (accountability, pertanggungjawaban); prinsip al kifayah (sufficiency) prinsip yang bertujuan membasmi kefakiran dan mencukupi kebutuhan primer seluruh

\footnotetext{
${ }^{33}$ Muhammad Yasir Yusuf, Islamic Corporate Social Responsibility..., Op. Cit., hlm. 44.

${ }^{34}$ Ibid.

${ }^{35}$ Ibid., hlm. 44

${ }_{36}$ Muhammad Syukri Albani Nasution, Filsafat Hukum Islam, Raja Grafindo Persada, Jakarta, 2013, hlm.

${ }^{37}$ Juhaya S. Praja, Filsafat Hukum Islam, Pusat Penerbitan Universitas LPPM-Universitas Islam Bandung,
} 114. 1995, hlm. 72 
anggota dalam masyarakat; prinsip keseimbangan prinsip al wasathiyah (al-i'tidal, moderat, keseimbangan; prinsip kejujuran dan kebenaran. ${ }^{38}$

Adapun terhadap lingkungan alam sekitar, Allah SWT berfirman yang artinya: "Dan apabila ia berpaling (dari kamu),ia berjalan di bumi untuk mengadakan kerusakan padanya merusak tanam-tanaman dan binatang ternak. Dan Allah SWT tidak menyukai kebinasaan". 39 Ayat ini secara teks menggambarkan secara nyata bagaimana Islam memberikan perhatian lebih untuk kelestarian alam sekitar. Secara konteks segala usaha, baik bisnis atau bukan harus menjaga kelestarian alam sekitar selamanya.

Pada sisi kebajikan sosial, Islam sangat mengajurkan derma kepada orangorang yang memerlukan dan kurang mampu dalam berusaha melalui sadaqah, ${ }^{40}$ dan pinjaman kebajikan (qard hasan). ${ }^{41}$ Allah SWT berfirman yang artinya:

“... dan nafkahkanlah yang baik untuk dirimu. Dan barang siapa yang dipelihara dari kekikiran dirinya maka mereka itulah orang-orang yang beruntung. (QS. Al-Taqabun, (64): 16)

Ayat di atas menjelaskan tanggung jawab seorang muslim untuk menolong sesamanya melalui sumbangan dan derma kebajikan serta segala sifat kikir sangat dibenci dalam Islam. ${ }^{22}$ Adapun pinjaman kebajikan (qard hasan) dijelaskan dalam Al-Quran yang artinya:

Siapakah yang mau memberi pinjaman kepada Allah SWT, pinjaman yang baik (menafkahkan hartanya di jalan Allah SWT), maka Allah SWT akan melipatgandakan pembayaran kepadanya dengan lipat ganda yang banyak. Dan Allah SWT menyempitkan dan melapangkan (rezeki) dan kepada-nya-lah kamu dikembalikan. ${ }^{43}$

Perbuatan memberikan pinjaman kebajikan selain memberi efek sosial, juga boleh mendatangkan keuntungan yang berlipat ganda baik kepada individu maupun perusahaan. Hal ini disebabkan tanggung jawab sosial dalam jangka

38 Sjaichul Hadi Permono, Formula Zakat, menuju kesejabteraan Sosial, Aulioa, Surabaya, 2005, hlm. 39-44

${ }^{39}$ QS. Al-Baqarah: 205

${ }^{40}$ Dalam Islam, kata sadaqah mempunyai dua makna, pertama, sadaqah yang bermakna derma wajib yaitu zakat dan kedua, derma sukarela seperti sumbangan kebajikan.Firdaus, "Sedekah Dalam Perspektif Al-Quran", Ash-Shababah Jurnal Pendidikan dan Studi Islam, Vol 3, No. 1, Januari 2017, hlm. 91.

${ }^{41}$ Qard hasan adalah kebajikan yang tidak mengambil keuntungan. Jumlah pengembaliannya pinjaman sesuai dengan jumlah harta yang dipinjamkan. Skim seperti ini hanya dikenal dalam Islam, Ibid.

42 Dalam Al-Quran, Allah SWT menyebutkan paling sedikit 64 ayat yang menjelaskan tentang penting melakukan derma kebajikan. Seperti pada 2:43, 83, 110, 177, 215, 263, 264, 270, 271, 273, 274, 276, 277, 280; 4:77, 114, 162; 5:12, 45, 55; 7:156 dan lain-lain. Penulisan 2:43 bermaksud, surah ke-2 dalam Al-Qur'an yaitu Albaqarah dan 43 bermaksud kepada ayat ke-43.

${ }^{43}$ QS. Al-Baqarab: 245. 
panjang menciptakan citra yang positif serta terbentuknya jaringan bisnis baru yang boleh menambahkan keuntungan.

Rasulullah bersabda dalam hadist yang diriwayatkan oleh Salman bin Amir:

"Sedekah atas orang miskin itu adalah sedekah. Dan sedekah atau kaum kebarabat mempunyai dua kepentingan, yaitu sedekah yang berpahala dan menghubungikan tali persaudaraan." (HR.Tirmizi, Hadis No.653)44

\section{Pendekatan Metode Filsafat Hukum Islam terhadap Konsep Tanggung Jawab Sosial Perusahaan (Corporate Social Responsibility)}

Filsafat berada pada ranah abstrak, dan filsafat hukum merupakan cabang dari filsafat. Filsafat hukum mempunyai fungsi yang strategis dalam pembentukan hukum. Secara konsep Islam menilai hukum tidak hanya berlaku di dunia saja, akan tetapi juga di akhirat, karena putusan kebenaran, atau ketetapan sanksi, di samping berhubungan dengan manusia secara langsung, juga berhubungan dengan Allah SWT. Di samping mengadopsi hukum yang langsung dari wahyu Tuhan dalam bentuk kitab suci, manusia juga dituntut untuk selalu mencari formula kebenaran, yaitu suatu hukum yang akan mengatur perjalanan masyarakat, dan hukum tersebut harus digali dengan metode filsafat hukum secara lebih komprehensif.45

Apabila beberapa kenyataan di atas dikaji melalui pendekatan teks bayani (tekstual), sehingga teks dianggap sebagai kebenaran mutlak, maka kita hanya menemukan prinsip-prinsip yang terkadung dalam hukum Islam terhadap lalulintas perekonomian dan bisnis tanpa penafsiran. Berkaitan dengan konsep CSR dapat dilakukan oleh perusahaan Islam atau tidak, maka diperlukan pendekatan burhani (rasional) dan irfani (intuitif, etis), kajian yang menempatkan pertimbangan realitas dan kajian mendalam terhadap apa yang ada dibalik teks menggunakan kejernihan hati. ${ }^{46}$ Jika prinsip-prinsip yang di atas dikaji dengan metode penemuan kebenaran hukum melalui metode argumentatif tentu memiliki kesimpulan yang berbeda.

\footnotetext{
${ }^{44}$ Muhammad Yasir Yusuf, Islamic Corporate Social Responsibility..., Op. Cit., hlm. 44.

${ }^{45}$ Muhammad Hasdin Has, "Kajian Filsafat Hukum Islam Dalam Al-Quran”, Jurnal Al-'Adl, Vol. 8 No. 2, Juli 2015, hlm. 58

46 Kuliah Filsafat Hukum Islam Magister Ilmu Hukum Fakultas Hukum Universitas Islam Indonesia Dr. Drs. Rohidin, S.H., M.Ag Tanggal 11 November 2017
} 
Salah satu pendekatan yang digunakan dalam tulisan ini adalah pendekatan metode $t a^{\prime}$ lili yaitu metode penemuan kebenaran hukum melalui metode argumentatif yang berorientasi pada eksistensi 'illat/causa/sebab hukum dengan prinsip hukum itu eksis bersama 'illatnya. Dikalangan ulama Ushul Fiqh, 'illat itu diartikan dengan sesuatu yang menjadi pautan hukum. 'Illat juga dapat disebut sebagai sesuatu yang menjadi alasan atau yang melatarbelakangi penetapan hukum syara'. Setiap ketentuan hukum yang diturunkan Allah baik perintah maupun larangan, pasti memiliki alasan-alasan tersendiri, yang disebut 'illat. ${ }^{47}$

Pengembangan hukum dengan penalaran ta'lili ini dilakukan dengan menggunakan 'illat, yang praktiknya, dapat ditempuh dengan 2 cara, yaitu dengan menggunakan 'illat qiyasi dan 'illat tasyri'i.48 Penulis mengganalisis permasalahan dalam konteks tulisan ini menggunakan cara 'illat qiyasi. Penggunaan 'illatqiyasi adalah cara yang menerapkan ketentuan hukum suatu masalah yang sudah dijelaskan oleh nash pada masalah lain yang tidak dijelaskan oleh dalil nash, karena ada kesamaan 'illat antara keduanya.

Teori qiyas memiliki 4 unsur penting yang harus diperhatikan yaitu: (1) alashl, yaitu pokok yang menjadi tempat sandaranqiyas, (2) al-far'u, yaitu masalah baru yang akan dicari ketentuan hukumnya, (3) al-'illat, yakni sifat atau keadaan yang menjadi alasan ditetapkannya hukum pada pokok, yang juga harus ditemukan pada masla'ah baru (cabang) yang belum ada ketentuan hukumnya, dan (4) hukum asalah, yaitu ketentuan hukum yang telah ditetapkan pada pokok, dan ketentuan hukum inilah nantinya yang akan diberlakukan kepada masalah baru yang belum ada ketentuan hukumnya itu. ${ }^{49}$

Banyak kententuan hukum yang ditetapkan dengan menggunakan teori qiyas atau dasar persamaan 'illat-nya. Prinsip qiyas adalah ketentuan-ketentuan hukum yang sudah dijelaskan dalam nash (pokok) dapat diberlakukan kepada persoalan-persoalan lain yang tidak disebutkan oleh nash, apabila terlihat kesamaan illat antara keduanya.50 Penalaran dengan menggunakan 'illat qiyas

47 Romli, "Illat dan Pengembangan Hukum Islam”, Intizar Vol. 20, No. 2, 2014, hlm. 222.

${ }^{48}$ Ibid., hlm. 223.

${ }^{49}$ Ibid. 97.

${ }_{50}$ Muhammad Hasyim Kamali, Principles of Islamic Jurisprudence, Dar al-Mal al-Islami, Geneva, 1997, hlm. 
dipakai secara luas dikalangan ulama ushul hingga sekarang. Banyak persoalanpersoalan baru yang tidak jelaskan nash al-Qur'an dan al-Sunnah mengenai ketentuan hukumnya secara tekstual, namun tetap dapat ditetapkan ketentuan hukumnya dengan menggunakan 'illat qiyas ini. Untuk itu dikemukakan contoh kasus yang berkaitan dengan penerapan 'illatqiyas ini.

Penjelasan diatas jika dikaitkan dengan konsep bisnis Islam yang telah dibawa oleh Nabi Muhammad SAW sesuai ketentuan Al-Quran dapat diketahui sebuah gambaran bahwa konsep tanggung jawab sosial dan konsep keadilan telah lama ada dalam Islam walaupun konsep CSR barat baru muncul dalam prinsip bisnis gelombang ke empat (fourth wave) pada 1930-an. ${ }^{51}$

Jika dikaitkan dengan karakteristik Nabi Muhammad SAW sebagai pedagang yaitu dedikasi dan keuletannya juga memiliki sifat shidiq, fathanah, amanah, dan tabligh, ciri-ciri itu masih ditambah dengan sifat istiqamah. Shidiq berarti mempunyai kejujuran dan selalu melandasi ucapan, keyakinan dan amal perbuatan atas dasar nilai-nilai yang diajarkan Islam. Istiqamah atau konsisten dalam iman dan nilai-nilai kebaikan, meski menghadapi godaan dan tantangan. Istiqamah dalam kebaikan ditampilkan dalam keteguhan, kesabaran serta keuletan sehingga menghasilkan sesuatu yang optimal. Fathanah berarti mengerti, memahami, dan menghayati secara mendalam segala yang menjadi tugas dan kewajibannya. Sifat ini akan menimbulkan kreatifitas dan kemampuan melakukan berbagai macam inovasi yang bermanfaat. Amanah, tanggung jawab dalam melaksanakan setiap tugas dan kewajiban. Amanah ditampilkan dalam keterbukaan, kejujuran, pelayanan yang optimal, dan ihsan (kebajikan) dalam segala hal. Tabligh, mengajak sekaligus memberikan contoh kepada pihak lain untuk melaksanakan ketentuan-ketentuan ajaran Islam dalam kehidupan seharihari. 52

Berdasarkan sifat-sifat tersebut, dalam konteks CSR, para pelaku usaha atau pihak perusahaan dituntut bersikap tidak kontradiksi secara disengaja antara

\footnotetext{
${ }^{51}$ K Bartens, Pengantar Etika Bisnis, Yogyakarta, Penerbit Kanisius, 2000, hlm. 20.

52 Biki Zulfikri Rahmat, "Corporate Social Responsibility Dalam Perspektif Etika Bisnis Islam”, Awaluna, Vol. 1 No. 1, Januari, 2017, hlm. 112.
} 
ucapan dan perbuatan dalam bisnisnya. Mereka dituntut tepat janji, tepat waktu, mengakui kelemahan dan kekurangan (tidak ditutup-tutupi), selalu memperbaiki kualitas barang atau jasa secara berkesinambungan serta tidak boleh menipu dan berbohong. Palu usaha atau pihak perusahaan harus memiliki amanah dengan menampilkan sikap keterbukaan, kejujuran, pelayanan yang optimal, dan ihsan (berbuat yang terbaik) dalam segala hal, apalagi berhubungan dengan pelayanan masyarakat. dengan sifat amanah, pelaku usaha memiliki tanggung jawab untuk mengamalkan kewajiban-kewajibannya. Sifat tablig dapat disampaikan pelaku usaha dengan bijak (hikmah), sabar, argumentatif dan persuasif akan menumbuhkan hubungan kemanusiaan yang solid dan kuat. ${ }^{53}$

Para pelaku usaha dituntut mempunyai kesadaran mengenai etika dan moral, karena keduanya merupakan kebutuhan yang harus dimiliki. Pelaku usaha atau perusahaan yang ceroboh dan tidak menjaga etika, tidak akan berbisnis secara baik sehingga dapat mengancam hubungan sosial dan merugikan konsumen, bahkan dirinya sendiri. Allah SWT berfirman "Dan janganlah kamu membuat kerusakan di muka bumi, sesudah Allah memperbaikinya dan berdo'alah kepada Allah dengan rasa takut (tidak akan diterima) dan harapan akan dikabulkan sesungguhnya Rahmat Allah sangat dekat kepada orang-orang yang berbuat baik".

Menurut Sayyid Qutb, Islam mempunyai prinsip pertanggungjawaban yang seimbang dalam segala bentuk dan ruang lingkupnya. Antara jiwa dan raga, antara individu dan keluarga, antara individu dan sosial, dan antara suatu masyarakat dengan masyarakat yang lain. Tanggung jawab sosial merujuk pada kewajiban-kewajiban sebuah perusahaan untuk melindungi dan memberi kontribusi kepada masyarakat dimana perusahaan itu berada. Sebuah perusahaan mengemban tanggung jawab sosial dalam tiga domain: ${ }^{44}$ Pertama, pelaku-pelaku organisasi, meliputi hubungan perusahaan dengan pekerja (QS. An-Nisa ayat 149), hubungan pekerja dengan perusahaan, dan hubungan perusahaan dan pelaku usaha lain, distributor, konsumen, pesaing; Kedua, lingkungan alam (QS. Al-A'raf ayat 56); Ketiga, kesejahteraan sosial masyarakat. 
Beberapa prinsip dalam Islam dalam menjalankan bisnis yang berkaitan dengan CSR yaitu menjaga lingkungan dan melestarikannya (Surat Al-Maidah ayat 32); upaya untuk menghapus kemiskinan (Surat Al-Hasyr ayat 7); mendahulukan sesuatu yang bermoral bersih daripada sesuatu yang secara moral kotor, walaupun mendatangkan keuntungan yang lebih besar (Surat Al-Maidah ayat 103); Jujur dan amanah (Surat Al-Anfal ayat 27).

Seiring dengan kehadiran Islam, Rasullullah SAW melaksanakan tanggung jawab sosial dan menciptakan keadilan berdasarkan petunjuk Al-Quran. Di samping itu, perbuatan Rasullulah dalam penerapan konsep tanggung jawab sosial dan keadilan dalam masyarakat, menjadi sumber rujukan bagi generasi setalah wafatnya Rasullulah SAW. Kedua konsep Al-Quran dan As-Sunnah berjalan dengan harmonis dan menciptakan keadilan seutuhnya. ${ }^{55}$ Prinsip-prinsip tanggung jawab sosial yang digariskan dalam Al-Quran dan As-Sunnah harus dijadikan pedoman bagi kaum muslimin dalam berbagai kegiatan termasuk dalam bisnis Islam.

Kajian dalam perspektif hukum Islam, di samping untuk menyusun konsep CSR dalam konteks bisnis Islam juga perlu melihat nilai-nilai persamaan CSR dalam Islam dengan konsep CSR yang berkembang di Barat. ${ }^{56}$ Zakat ataupun CSR keduanya memiliki tujuan akhir yang sama yaitu usaha untuk menciptakan kesejahteraan sosial dalam masyarakat. ${ }^{57} \mathrm{Di}$ samping perusahaan berusaha meraih keuntungan untuk pemegang saham tetapi juga menjaga dan mengembangkan sumber daya ekonomi masyarakat. ${ }^{58}$ Paradigma takwa pula melahirkan

55 Adil "AdP" Artinya: "Sama"/Tidak berat sebelah/tidak memihak, berpihak kepada kebeneran, sepatutnya/tidak sewenang-wenang. Keadilan diungkapkan oleh Al-Quran dengan Kata-Kata Al-'ADL, Al-Qisth, Al-Mizan. Lazimnya Kata ini berlawanan dengan kezaliman., "ADL" berarti "Sama", memberi kesan adanya dua pihak/lebih, karena jika hanya satu pihak tidak akan terjadi "persamaan", Qisth" artinya "bagian" yang patut (Tidak harus ada "Persamaan"). Kata Qisthi lebih umum dari pada kata "ADL" sehingga keadilan untuk diri sendiri menggunakan kata "QISTH", Kata Mizan berarti timbangan, oleh karena itu, mizan adalah alat untuk menimbang. Alquran menetapkan bahwa salah satu sendi kehidupan bermasyarakat adalah keadilan. Tidak lebih dan tidak kurang. Berbuat baik melebihi keadilan-seperti memaafkan yang bersalah atau memberi bantuan kepada yang malas akan dapat menggoyahkan sendi-sendir kehidupan bermasyarakat. Al Quran memerintahkan perbuatan adil dan kebaikan (Q.S An-nahl: 16), karena ihsan (kebajikan) dinilai sebagai sesuau yang melebihi keadilan. Namun dalam kehidupan bermasyarakat, keadilan lebih utama daripada kedermawanan atau ihsan.Muhammad Yasir Yusuf, Islamic Corporate Social Responsibility..., Op. Cit., hlm. 9

${ }^{56}$ Ibid.

${ }^{57}$ Ibid.

${ }^{58}$ Ibid. 
pemahaman yang mendalam terhadap manajemen dan pengembangan pembangunan mesti dikelola sesuai dengan nilai-nilai syariah. Paradigma takwa ini akan melahirkan konsep pelaksanaan CSR yang bertumpu pada menjaga martabat manusia, kebebasan berusaha, keadilan dan pengakuan hak individu, kepercayaan dan tanggung jawab. 59

Bila dihubungkan dengan filsafat hukum Islam dengan pendekatan metode Ta'lili,dapat ditarik pemahaman bahwa ketika suatu ketentuan hukum tidak dapat dilaksanakan atau direalisasikan dalam kehidupan, maka harus melihat kembali 'illat yang mendasari penetapannya. Artinya, harus mengubah dan merumuskan kembali pemahaman 'illat yang mendasari penetapan hukum tersebut, dengan melihat konteks perubahan zaman, keadaan dan tempat, dan tujuan pensyari'atan hukum itu sendiri. Inilah yang disebut oleh Mustafa Syalabi dengan istilah hukum berupah karena terjadinya perubahan kepentingan. ${ }^{60}$

Beberapa penjelasan di atas dapat menggambarkan dengan cukup jelas bahwa, Pertama, aktivitas CSR dalam Islam bukan hanya bersifat melaksanakan perintah undang-undang atau tanggung jawab kepada masyarakat ataupun untuk mendapatkan pandangan dari masyarakat sehingga mendapatkan keuntungan lebih besar seperti prinsip yang dianut oleh CSR barat. Aktivitas CSR Islam tidak hanya melihat dari sisi ekonomi yang bersifat materi saja atau adanya perintah undang-undang akan tetapi juga bertumpu pada nilai-nilai rohani dan atas rasa tanggung jawab terhadap perintah Allah SWT.

Kedua, aktivitas CSR dalam Islam mempunyai garis panduan antara halal dengan haram dan harus menjadi ukuran tetap yang tidak akan pernah berubah sepanjang zaman karena didasarkan pada syariah. Tidak ada satu perusahaan pun bisa melakukan aktivitas CSR yang bertentangan dengan nilai dan etika Islam. Inilah yang membedakan CSR pada umumnya dengan CSR dalam Islam.Pelaksanaan CSR Islam memiliki nilai falsafah yang digali dari Al-Quran dan As-Sunnah, kemudian menjadi pedoman dalam berbagai aktivitas kehidupan tidak terkecuali dalam pelaksanaan CSR terhadap perusahaan yang dibangun

\footnotetext{
${ }^{59}$ Muhammad Yasir Yusuf, Islamic Corporate Social Responsibility (I-CSR)..., Op. Cit., hlm. 9.

${ }^{60}$ Biki Zulfikri Rahmat, Corporate Social Responsibility dalam..., Op. Cit., hlm. 112.
} 
berdasarkan nilai-nilai Islam. Falsafah Islam menjadi ruh yang akan membedakan nilai yang datangnya dari Islam atau bukan dari Islam.

\section{Penutup}

Berdasarkan analisis dan pembahasan di atas, dapat ditarik kesimpulan bahwa konsep tanggung jawab sosial perusahaan (Corporate Social Responsibility) dalam Islam sudah mulai ada dan dipraktikkan sejak 14 abad lalu. Pembahasan mengenai tanggung jawab sosial sangat sering disebutkan dalam Al-Quran dan Sunnah. Kedua sumber hukum tersebut selalu menghubungkan antara kesuksesan berbisnis dan pertumbuhan ekonomi yang dipengaruhi oleh moral para pengusaha dalam menjalankan bisnis.

Apabila dikaji melalui pendekatan metode ta'lili yaitu metode penemuan kebenaran hukum melalui metode argumentatif yang berorientasi pada eksistensi 'illat/causa/sebab hukum dengan prinsip hukum itu eksis bersama'illatnya. Kenyataan di atas menunjukkan bahwa konsep tanggung jawab sosial dan konsep keadilan telah lama ada dalam Islam walaupun konsep CSR barat baru muncul pada prinsip bisnis gelombang ke empat (Fourth Wave)pada tahun 1930-an. Seiring dengan kehadiran Islam, Rasullullah SAW melaksanakan tanggung jawab sosial dan menciptakan keadilan berdasarkan petunjuk Al-Quran. Di samping itu, perbuatan Rasullulah SAW dalam penerapan konsep tanggung jawab sosial dan keadilan dalam masyarakat, menjadi sumber rujukan bagi generasi setalah Wafatnya Rasullulah SAW, ia berfungsi sebagai As-Sunnah Rasulullah. Kedua konsep AlQuran dan As-Sunnah berjalan dengan harmonis dan menciptakan keadilan seutuhnya. Dengan demikian, prinsip-prinsip tanggung jawab sosial yang telah digariskan dalam Al-Quran dan As-Sunnah harus dijadikan pendoman bagi kehidupan kaum muslimin dalam berbagai kegiatan termasuk dalam bisnis Islam.

\section{Daftar Pustaka}

\section{Buku}

Al-Habsyi, M. B., Fiqih Praktis Menurut Al-Qur'an Assunah, Pendapat Para Ulama, Mirzan, Bandung, 1999.

Al-Zuhayly, W., Zakat Kajian Berbagai Mashab, Remaja Rosdakarya, Bandung, 2008. 
Ali, Muhammad Daud, Sistem Ekonomi Islam Zakat dan Wakaf, UI Press, Jakarta, 1988.

Amirruddin, \& H. Zainal Asikin, Pengantar Metode Penelitian Hukum. PT. Raja Grafindo Persada, Jakarta, 2003.

Anshori, A. G., \& Yulkarnain Harahap, Hukum Islam Dinamika dan Perkembangannya di Indonesia, Thafa Media, Yogyakarta, 2008.

Bartens, K., Pengantar Etika Bisnis, Penerbit Kanisius, Yogyakarta, 2000.

Djamil, F., Filsafat Hukum Islam, Logos Wacana Ilmu, Ciputat, 1997.

Faisal, Bardoen, dkk., Etika Bisnis dalam Islam, Kencana Prenada Media Group, Jakarta, 2006.

Ismail, Muhammad, dkk., Filsafat Hukum Islam, Bumi Aksara, Jakarta, 1999.

Huda, Joko, Prastowo, Corporate Social Responsibility Kunci Merih Kemuliaan Bisnis, Samudra Biru, Yogyakarta, 2011.

Badan Pembinaan Hukum Nasional Departemen Hukum dan HAM Republik Indonesia, Tanggung Jawab Sosial Perusahan, Kementerian Hukum dan HAM, Jakarta, 2009.

Kamali, M. H., Principles of Islamic Jurisprudence, Daral-Malal-Islami, Geneva, 1997.

Korten, D. C., When Corporation Rule The World Terjamahan oleh Agus Maulana, Rajawali Press, Jakarta, 1995.

Mahmud, A., Bank Syari'ah Teori, Kebijakan dan Studi Empiris di Indonesia, Erlangga, Jakarta, 2010.

Marzuki, P. M., Penelitian Hukum Normatif Cetakan I, Kencana, Jakarta, 2005.

Muhammad, Aspek Hukum dalam Mu'amalat, Graha Ilmu, Yogyakarta, 2007.

N.D, Mukti. Fajar., Tanggung Jawab Sosial Perusahaan di Indonesia Mandatory vs Voluntary Studi Tentang Penerapan Ketentuan Corporate Social Responsibility Pada Perusahaan Multi Nasional, Swasta Nasional dan Badan Usaha Milik Negara, Pustaka Pelajar, Jakarta, 2009.

N.D, Mukti. Fajar., \& Achmad, Y., Dualisme Penelitian Hukum Normatif E Empiris, Penerbit Pustaka Pelajar, Yogyakarta, 2009.

Nasution, M. S., Filsafat Hukum Islam, Raja Grafindo Persada, Jakarta, 2013.

Permono, S. H., Formula Zakat, Menuju Kesejahteraan Sosial, Aulioa, Surabaya, 2005.

Praja, J. S., Filsafat Hukum Islam, Pusat Penerbitan Universitas LPPM Universias Islam Bandung, Bandung, 2002.

Shomad, Abd., Hukum Islam Penormaan Prinsip Syariah Dalam Hukum Indonesia, Kencana Prenada Media Group, Jakarta, 2012.

Suharto, E., CSR \& Comdev Investasi Kreatif Perusahaan di Era Globalisasi, Alfabeta, Bandung, 2010.

Wignjosoebroto, S., Hukum, Konsep dan Metode, Setara Press, Malang, 2013. 
Yusuf, M. Y., Islamic Corporate Social Responsibility (I-CSR) Pada Lembaga Keuangan Syariah (LKS) Teori dan Praktik, Kencana Prenada Media Group, Jakarta, 2017.

\section{Jurnal}

Firdaus, "Sedekah Dalam Perspektif Al-Quran". Ash-Shahabah Jurnal Pendidikan dan Studi Islam, Vol. 3, No. 1, Januari 2017.

Has, Muhammad Hadin, "Kajian Filsafat Hukum Islam Dalam Al-Quran”, Jurnal Al-Adl, Vol. 8 No. 2, 2015.

Rahmat, B. Z., "Corporate Social Responsibility Dalam Perspektif Etika Bisnis Islam", Awaluna, Vol. 1 No. 1 122, 2017.

Romli, "Illat dan Pengembangan Hukum Islam”, Intizar Vol. 20., No. 2, 222, 2014

\section{Karya Ilmiah}

Mohammed, J. A., "Corporate Social Responsibility in Islam", Thesis Auckland University of Technology, New Zealand, 2009.

Wijaya, A., "Bahaya Khamar Dalam Perspektif Al-Quran dan Kesehatan", Skripsi Fakultas Ushuludin dan Studi Islam Negeri Sumatera Utara, Medan, 2016.

\section{Internet}

www.ekatjicptafoundation.org

https: / / media.neliti.com/media/publications/164479-ID-none.pdf

\section{Peraturan Perundang-Undangan}

Undang-Undang Dasar Negara Republik Indonesia Tahun 1945

Undang-Undang Nomor 25 Tahun 2007 tentang Penanaman Modal

Undang-Undang Nomor 40 Tahun 2007 tentang Perseroan Terbatas

Peraturan Pemerintah Nomor 47 Tahun 2012 tentang Tanggung Jawab Sosial dan Lingkungan 